Gut, 1987, 28, S1, 175-180

\title{
Pathogenesis of the mucosal hyperplasia in self-filling blind loops of rat jejunum: a morphometric study in germ free animals
}

\author{
H MENGE, CH-TH GERMER, R STÖSSEL, G SIMES, H HAHN, \\ AND E O RIECKEN
}

From the Klinikum Steglitz, Abteilung für innere Medizin mit Schwerpunkt Gastroenterologie und Institut für medizinische Mikrobiologie, Freie Universität, Berlin, FRG

SUMMARY Bacterial overgrowth and high intraluminal concentrations of deconjugated bile acids are thought to be responsible for mucosal hyperplasia in self-filling blind loops of rat jejunum. To investigate this hypothesis further we have assessed the three dimensional architecture of these loops created in germ free animals without or with di- or mono-association of different bacterial species. It was found that mucosal hyperplasia develops in the absence of any bacterial contamination and that bacterial association does not lead to a more pronounced mucosal proliferation. This implies that other mechanisms provoke this morphological phenomenon. Increased bulk contents in these loops or immunological events are probably the most likely explanation.

The stagnant loop syndrome is characterised by bacterial overgrowth and a consecutive increase in deconjugation of conjugated bile acids. The luxuriant flora and the high concentrations of deconjugated bile acids are thought to be responsible for the morphological alterations of the small intestine seen in this condition. ${ }^{1-3}$

The present study was undertaken in order to investigate further the hypothesis that the noxious intraluminal content evokes the mucosal hyperplasia seen in the stagnant loop syndrome. ${ }^{45}$ As an experimental model for this condition in man, self-filling blind loops of rat jejunum were used, because the most pronounced morphological alterations in response to bacterial overgrowth are seen in these loops. ${ }^{6}$ In a first experiment, self-filling blind loops were created in germ free rats. When compared with sham operated germ free controls, these loops revealed mucosal hyperplasia which seemed to be less pronounced than in conventional animals. Thereafter, germ free rats with self-filling blind loops were associated with bacteria that exhibit overgrowth in conventional animals ${ }^{7}$ with stagnant loops in order to elucidate to what extent the different germs may

Address for correspondence: Prof Dr med Heinz Menge, Klinikum Steglitz der Freien Universität Berlin, Medizinische Klinik und Poliklinik, Abteilung für innere Medizin mit Schwerpunkt Gastroenterologie, Hindenburgdamm 30, D-1000 Berlin 45, West Germany. contribute to the morphological alterations seen in the latter animals.

\section{Methods}

Male Wistar rats with a body weight of between 200 and $350 \mathrm{~g}$ were used. Care was taken that the body weight of the control and experimental animals did not differ from each other in the individual experiments. The rats were nourished with sterile water and sterile standard pellet food ad libitum.

The following groups of germ free animals reared and kept in PVC-isolators were investigated (surgical creation of the jejunal blind loops and sham operations were done in sterile environment as described earlier $;{ }^{5} \mathrm{cfu}=$ colony-forming units): experiment (1): control animals: sham-operation, experimental rats: self-filling blind loops. Experiment (2): control animals: self-filling blind loops, experimental rats: self-filling blind loops and intragastric inoculation of $E$ coli $\left(2.6 \times 10^{8} \mathrm{cfu}\right)$ and Enterococcus $\left(1.7 \times 10^{9} \mathrm{cfu}\right)$. Experiment (3): control animals: self-filling blind loops, experimental rats: self-filling blind loops and intragastric inoculation of Bacteroides asaccharolyticus $\left(4.5 \times 10^{9} \mathrm{cfu}\right)$. Experiment (4): control animals : self-filling blind loops, experimental rats: self-filling blind loops and intragastric inoculation of Lactobacillus minutus $\left(1.9 \times 10^{9} \mathrm{cfu}\right)$. 
During the first two days after these operations, all animals received only a solution consisting of a mixture of equal parts of $150 \mathrm{mmol} / 1 \mathrm{NaCl}$ and 300 $\mathrm{mmol} / \mathrm{l}$ glucose; thereafter, pellet food was offered again ad libitum. On the third postoperative day, intragastric inoculation of the above outlined bacteria was carried out using a stainless steel feeding tube. The bacteria had been cultured from self-filling blind loops of conventional rats, ${ }^{7}$ - that is, they were adapted to the self-filling blind loop intraluminal environment.

Three weeks after the intragastric inoculation, the control and experimental animals of each group received an injection of vincristine sulphate $(1 \mathrm{mg} / \mathrm{kg}$ body weight intraperitoneally, at intervals of $15 \mathrm{~min}$ starting at $700 \mathrm{am}$ ) two hours before the self-filling blind loops or corresponding jejunal segments of sham-operated animals were excised under sterile conditions for study.

\section{BACTERIOLOGY}

All intestinal segments were rinsed with $2 \mathrm{ml}$ sterile $\mathrm{NaCl}$ solution to evaluate the intraluminal bacterial flora of the di- or mono-associated animals and the germ free state of the control rats. The method used for the qualitative and quantitative microbiological investigation has been published earlier. ${ }^{7}$

\section{MICRODISSECTION}

The microdissection of the intestine was done as described by Clarke. ${ }^{8}$ Tissue samples were fixed in ethanol/glacial acetic acid $(3: 1, \mathrm{v} / \mathrm{v}$ for $24 \mathrm{~h})$ then rinsed with and stored in $75 \%$ ethanol. The samples were stained with the Feulgen reagent, and thereafter, microdissection was carried out under a stereomicroscope to liberate individual structural units. From each sample, 10 villus crypt units were isolated at random for measurement of crypt length, villus height, villus length at the base and apex, and villus width. From these values, the villus surface could be calculated. By multiplying the mean surface area of the single villus with the number of villi per unit serosal area (obtained from photographs) the absorptive surface area was determined. The number of crypts per unit serosal area was also taken from photographs. Furthermore, 10 crypts of the 10 isolated villus crypt units were dissected and the vincristine arrested mitoses per crypt were counted under a binocular microscope.

\section{STATISTICAL ANALYSIS}

The bacterial concentrations (colony-forming units/ $\mathrm{ml}$ intestinal contents) are given in each case as median of the individual values of each animal group. The morphometric data are expressed as $\mathrm{x} \pm \mathrm{SEM}$. For statistical evaluation the Student's $t$ test was used; $p$ values of $<0.05$ were taken to be significant.

\section{Results}

\section{EXPERIMENT 1}

The microbiological investigations proved that the intraluminal content was sterile in both sets of animals. The microdissection data revealed mucosal hyperplasia in the self-filling blind loops when compared with the sham operated controls (Table 1). There was a significant increase in villus height and in villus length both at base and at apex so that the surface of the individual villi was significantly enlarged. This enlargement of the individual mucosal structure led to a decrease in the number of villi per unit serosal area, but because of the enlargement of the individual villi, the mucosal surface area per unit serosal area remained unchanged. Likewise, the proliferation compartment exhibited hyperplasia. Crypt length and the number of mitoses per crypt were significantly increased and the number of crypts per unit serosal area was significantly decreased.

Table 1 Morphometric data and calculated values ( $x \pm S E M)$ obtained on the mucosa of jejunal segments of sham operated germ free rats and of jejunal self-filling blind loops of germ free animals. $N S=$ not significant.

\begin{tabular}{lccc}
$\begin{array}{l}\text { Mucosal } \\
\text { parameter }\end{array}$ & $\begin{array}{l}\text { Germ free rats } \\
+ \text { sham operation } \\
(n=10)\end{array}$ & $\begin{array}{l}\text { Germ free rats } \\
+ \text { self-filling } \\
\text { blind loops } \\
(\boldsymbol{n}=10)\end{array}$ & $\begin{array}{l}\text { Statistical } \\
\text { evaluation }\end{array}$ \\
\hline Villus height $(\mu \mathrm{m})$ & $475.0 \pm 20.1$ & $538.9 \pm 20.5$ & $\mathrm{p}<0.05$ \\
Villus length of apex $(\mu \mathrm{m})$ & $308.0 \pm 9.9$ & $337.0 \pm 10.4$ & $\mathrm{p}<0.05$ \\
Villus length at base $(\mu \mathrm{m})$ & $357.4 \pm 7.6$ & $386.4 \pm 11.0$ & $\mathrm{p}<0.05$ \\
Villus surface $\left(\mathrm{mm}^{2}\right)$ & $0.35 \pm 0.02$ & $0.43 \pm 0.02$ & $\mathrm{p}<0.01$ \\
Number of villi per $\mathrm{mm}^{2}$ serosa & $22.9 \pm 1.7$ & $18.9 \pm 1.0$ & $\mathrm{p}<0.05$ \\
Mucosal surface per $\mathrm{mm}^{2}$ serosa & $8.0 \pm 0.6$ & $8.0 \pm 0.6$ & $\mathrm{NS}$ \\
Crypt length $(\mu \mathrm{m})$ & $131.4 \pm 5.0$ & $265.1 \pm 15.5$ & $\mathrm{p}<0.01$ \\
Number of crypts per $\mathrm{mm}^{2}$ serosa & $207.0 \pm 6.5$ & $172.6 \pm 9.1$ & $\mathrm{p}<0.01$ \\
Number of mitoses per crypt and 2 hours & $24.8 \pm 1.6$ & $31.3 \pm 2.4$ & $\mathrm{p}<0.05$ \\
\hline
\end{tabular}


Table 2 Morphometric data and calculated values ( $x \pm S E M)$ obtained on the mucosa of jejunal self-filling blind loops of germ free rats. Experimental animals were di-associated with $E$ coli and Enterococcus. $N S=$ not significant.

\begin{tabular}{|c|c|c|c|}
\hline $\begin{array}{l}\text { Mucosal } \\
\text { parameter }\end{array}$ & $\begin{array}{l}\text { Germ free rats } \\
+ \text { self-filling } \\
\text { blind loops } \\
(n=7)\end{array}$ & $\begin{array}{l}\text { Germ free rats } \\
+ \text { self-filling } \\
\text { blind loops } \\
+E \text { coli and } \\
\text { Enterococcus } \\
(n=8)\end{array}$ & $\begin{array}{l}\text { Statistical } \\
\text { evaluation }\end{array}$ \\
\hline $\begin{array}{l}\text { Villus height }(\mu \mathrm{m}) \\
\text { Villus length of apex }(\mu \mathrm{m}) \\
\text { Villus length at base }(\mu \mathrm{m}) \\
\text { Villus surface }\left(\mathrm{mm}^{2}\right) \\
\text { Number of villi per } \mathrm{mm}^{2} \text { serosa } \\
\text { Mucosal surface per } \mathrm{mm}^{2} \text { serosa } \\
\text { Crypt length }(\mu \mathrm{m}) \\
\text { Number of crypts per } \mathrm{mm}^{2} \text { serosa } \\
\text { Number of mitoses per crypt and } 2 \text { hours }\end{array}$ & $\begin{aligned} 386 \cdot 2 & \pm 17 \cdot 7 \\
251 \cdot 8 & \pm 7 \cdot 8 \\
297 \cdot 1 & \pm 8 \cdot 5 \\
0 \cdot 25 & \pm 0 \cdot 017 \\
18 \cdot 4 & \pm 0 \cdot 6 \\
4 \cdot 6 & \pm 0 \cdot 2 \\
219 \cdot 8 & \pm 7 \cdot 6 \\
155 \cdot 7 & \pm 8 \cdot 3 \\
20 \cdot 9 & \pm 1 \cdot 1\end{aligned}$ & $\begin{array}{l}413 \cdot 6 \pm 9 \cdot 5 \\
278 \cdot 8 \pm 6 \cdot 5 \\
320 \cdot 0 \pm 5 \cdot 4 \\
0 \cdot 28 \pm 0 \cdot 012 \\
16 \cdot 8 \pm 1 \cdot 5 \\
4 \cdot 9 \pm 0 \cdot 6 \\
220 \cdot 7 \pm 4 \cdot 2 \\
129 \cdot 5 \pm 10 \cdot 1 \\
20 \cdot 8 \pm 1 \cdot 8\end{array}$ & $\begin{array}{l}\text { NS } \\
\mathrm{p}<0.01 \\
\mathrm{p}<0.05 \\
\text { NS } \\
\text { NS } \\
\text { NS } \\
\text { NS } \\
\text { NS } \\
\text { NS }\end{array}$ \\
\hline
\end{tabular}

Table 3 Morphometric data and calculated values ( $x \pm S E M)$ obtained on the mucosa of jejunal self-filling blind loops of germ free rats. Experimental animals were mono-associated with Bacteroides asaccharolyticus. NS = not significant.

\begin{tabular}{|c|c|c|c|}
\hline $\begin{array}{l}\text { Mucosal } \\
\text { parameter }\end{array}$ & $\begin{array}{l}\text { Germ free rats } \\
+ \text { self-filling } \\
\text { blind loops } \\
(n=6)\end{array}$ & $\begin{array}{l}\text { Germ free rats } \\
\text { + self-filling } \\
\text { blind loops } \\
\text { + Bacteroides } \\
\text { asaccharolyticus } \\
(n=6)\end{array}$ & $\begin{array}{l}\text { Statistical } \\
\text { evaluation }\end{array}$ \\
\hline $\begin{array}{l}\text { Villus height }(\mu \mathrm{m}) \\
\text { Villus length of apex }(\mu \mathrm{m}) \\
\text { Villus length at base }(\mu \mathrm{m}) \\
\text { Villus surface }\left(\mathrm{mm}^{2}\right) \\
\text { Number of villi per } \mathrm{mm}^{2} \text { serosa } \\
\text { Mucosal surface per } \mathrm{mm}^{2} \text { serosa } \\
\text { Crypt length }(\mu \mathrm{m}) \\
\text { Number of crypts per } \mathrm{mm}^{2} \text { serosa } \\
\text { Number of mitoses per crypt and } 2 \text { hours }\end{array}$ & $\begin{aligned} 390 \cdot 1 & \pm 25 \cdot 6 \\
270 \cdot 1 & \pm 11 \cdot 0 \\
325 \cdot 0 & \pm 10 \cdot 7 \\
0 \cdot 27 & \pm 0 \cdot 02 \\
16 \cdot 3 & \pm 0 \cdot 8 \\
4 \cdot 5 & \pm 0 \cdot 6 \\
238 \cdot 1 & \pm 14 \cdot 6 \\
141 \cdot 7 & \pm 6 \cdot 7 \\
32 \cdot 3 & \pm 1 \cdot 0\end{aligned}$ & $\begin{array}{c}431 \cdot 3 \pm 14 \cdot 0 \\
273 \cdot 4 \pm 4 \cdot 3 \\
324 \cdot 8 \pm 4 \cdot 0 \\
0 \cdot 29 \pm 0 \cdot 09 \\
21 \cdot 8 \pm 1 \cdot 6 \\
6 \cdot 5 \pm 0 \cdot 6 \\
231 \cdot 2 \pm 6 \cdot 8 \\
158 \cdot 0 \pm 7 \cdot 4 \\
32 \cdot 6 \pm 1 \cdot 1\end{array}$ & $\begin{array}{l}\text { NS } \\
\text { NS } \\
\text { NS } \\
\text { NS } \\
\mathrm{p}<0.01 \\
\mathrm{p}<0.05 \\
\mathrm{NS} \\
\mathrm{NS} \\
\mathrm{NS}\end{array}$ \\
\hline
\end{tabular}

\section{EXPERIMENT 2}

All di-associated self-filling blind loops revealed a luxuriant growth of the inoculated bacteria $(E$ coli: $4.5 \times 10^{7} \mathrm{cfu}$, Enterococcus: $3.8 \times 10^{9} \mathrm{cfu}$ ) only. The control animals were without bacterial growth. The morphometric evaluation showed no differences in villus height in the control and experimental animals (Table 2). There was only a significant increase in villus length both at base and apex in the di-associated animals, but these changes were not sufficient to increase the surface area of the individual villi. There was no difference in the other values between both sets of animals, and this was especially true for crypt length and the number of mitoses per crypt.

\section{EXPERIMENT 3}

The initial intragastric inoculation again resulted in a remarkable overgrowth of the inoculated bacterium (Bacteroides asaccharolyticus: $2.8 \times 10^{8} \mathrm{cfu}$ ) in the self-filling blind loops. No other bacteria could be cultured. The control intestines proved to be without bacterial growth. The morphometric measurements did not show any differences in the parameters contributing to the architecture of the individual villi in both sets of animals (Table 3). There was, however, an inexplicable increase in the number of villi per unit serosal area and therefore a concomitant increase in the absorptive surface area in the experimental animals. Again the proliferation compartment revealed no differences between the two animal groups.

\section{EXPERIMENT 4}

As in the other experiments, the inoculation led to a significant overgrowth of the inoculum (Lactobacillus minutus: $\left.5.5 \times 10^{8} \mathrm{cfu}\right)$. The control intestines remained without bacterial growth.

As in the second experiment, there was only a significant increase in villus length at base and apex in the mono-associated animals which again was not 
Table 4 Morphometric data and calculated values $(x \pm S E M)$ obtained on the mucosa of jejunal self-filling blind loops of germ free rats. Experimental animals were mono-associated with Lactobacillus minutus. NS = not significant.

\begin{tabular}{|c|c|c|c|}
\hline $\begin{array}{l}\text { Mucosal } \\
\text { parameter }\end{array}$ & $\begin{array}{l}\text { Germ free rats } \\
+ \text { self-filling } \\
\text { blind loops } \\
(n=6)\end{array}$ & $\begin{array}{l}\text { Germ free rats } \\
+ \text { self-filling } \\
\text { blind loops } \\
+ \text { Lactobacillus } \\
\text { minutus } \\
(n=7)\end{array}$ & $\begin{array}{l}\text { Statistical } \\
\text { evaluation }\end{array}$ \\
\hline $\begin{array}{l}\text { Villus height }(\mu \mathrm{m}) \\
\text { Villus length of apex }(\mu \mathrm{m}) \\
\text { Villus length at base }(\mu \mathrm{m}) \\
\text { Villus surface }\left(\mathrm{mm}^{2}\right) \\
\text { Number of villi per } \mathrm{mm}^{2} \text { serosa } \\
\text { Mucosal surface per } \mathrm{mm}^{2} \text { serosa } \\
\text { Crypt length }(\mu \mathrm{m}) \\
\text { Number of crypts per } \mathrm{mm}^{2} \text { serosa } \\
\text { Number of mitoses per crypt and } 2 \text { hours }\end{array}$ & $\begin{aligned} 478 \cdot 0 & \pm 37 \cdot 4 \\
263 \cdot 8 & \pm 9 \cdot 0 \\
317 \cdot 4 & \pm 8 \cdot 3 \\
0 \cdot 32 & \pm 0 \cdot 03 \\
18 \cdot 5 & \pm 1 \cdot 4 \\
5 \cdot 9 & \pm 0 \cdot 9 \\
233 \cdot 3 & \pm 15 \cdot 2 \\
158 \cdot 7 & \pm 10 \cdot 8 \\
29 \cdot 0 & \pm 4 \cdot 1\end{aligned}$ & $\begin{array}{c}550 \cdot 0 \pm 44 \cdot 9 \\
316 \cdot 1 \pm 13 \cdot 6 \\
372 \cdot 9 \pm 20 \cdot 0 \\
0 \cdot 44 \pm 0 \cdot 05 \\
18 \cdot 4 \pm 1 \cdot 5 \\
7 \cdot 9 \pm 1 \cdot 1 \\
293 \cdot 4 \pm 26 \cdot 5 \\
163 \cdot 0 \pm 9 \cdot 7 \\
38 \cdot 3 \pm 4 \cdot 3\end{array}$ & $\begin{array}{l}\text { NS } \\
\mathrm{p}<0.01 \\
\mathrm{p}<0.05 \\
\text { NS } \\
\text { NS } \\
\text { NS } \\
\text { NS } \\
\text { NS } \\
\text { NS }\end{array}$ \\
\hline
\end{tabular}

big enough to indicate a difference in individual villus surface area between control and experimental animals (Table 4). All other parameters characterising the morphology of the absorptive and proliferative compartment were unchanged.

\section{Discussion}

The results of the first experiment show convincingly that self-filling blind loops in germ free rats are characterised by mucosal hyperplasia when the small intestinal architecture is compared with corresponding jejunal segments of sham operated germ free control animals. These structural alterations which developed despite the absence of any intraluminal bacterial growth are the first indication that the central role of bacterial overgrowth in the pathogenesis of mucosal transformation has to be seriously questioned. On the other hand, the hyperplasia seems to be less pronounced than in self-filling blind loops in conventional animals. For this reason it could be suspected that the high bacterial colonisation of the latter loops is not exclusively responsible for but contributes to the mucosal transformation seen in those animals living in a normal environment as also suspected by Giannella et $a l^{4}$ and Menge et al..$^{5}$ To further the investigation of this hypothesis di- or mono-associated germ free rats with self-filling blind loops with those bacteria which have been found to be significantly increased in number in the stagnant loop syndrome in rats. ${ }^{7}$ And using different bacterial species, it is hoped to find out additionally whether certain germs might contribute in different degrees to the hyperplasia observed in this condition.

According to procedure chosen we succeeded in establishing very high intraluminal concentrations of the inoculated bacteria which were in some cases even higher than in conventional rats with self-filling blind loops. This means that with bacterial overgrowth the situation in the experimental rats was comparable with that seen in the above mentioned animals. In addition, the germs which were cultured from ordinary blind loops and with which the germ free rats were inoculated are generally able to deconjugate conjugated bile acids. This could be shown in vitro, ${ }^{9}$ and is probably also true in vivo as high concentrations of deconjugated bile acids are found in self-filling blind loops with bacterial overgrowth. ${ }^{6111}$ The evidence for this bacterial action is further supported by the fact that in contrast with germ free rats, conventional animals excrete deconjugated bile acids. ${ }^{12}$ With these two facts in mind, the inoculation led to a situation similar to that in conventional animals with respect to bacterial overgrowth and the intraluminal concentrations of deconjugated bile acids. The monoassociation carried out does not contradict this similarity as bacterial overgrowth in conventional animals can also be restricted to one or several species. ${ }^{7}$ The advantage of the model chosen, however, was the overgrowth of only one or two strains of bacteria. So it could be hoped to see how far these specific bacteria contribute to the observed mucosal transformation. An additional advantage is the use of germ free rats with self-filling blind loops as controls.

In spite of the fact that, in the experiments $2-4$, the two main noxious agents thought to be responsible for the observed mucosal transformation were present in the intestinal lumen, no substantial differences in the mucosal architecture could be shown when the data were compared with those of corresponding loops in germ free animals. From these results, two main conclusions can be drawn: first, bacterial overgrowth is not responsible, nor does it even contribute to the mucosal hyperplasia seen in blind loops of conventional rats. This implies that the effect of bacterial overgrowth on the mucosa of self-filling 
blind loops is restricted to brush border damage (including enzyme activities) of the individual enterocytes. This is provoked by the production of proteases, as seen in man and animals. ${ }^{1314}$ The second main conclusion is that deconjugated bile acids do not affect the mucosal structure in the blind loops. This means that their influence on the mucosa in the stagnant loop syndrome is restricted to interactions with the brush border membrane enzymes ${ }^{1516}$ and with transport processes ${ }^{17-19}$ and to individual cell damage. ${ }^{420}$

According to our data alternative explanations for the observed mucosal transformation have to be considered. Because it is unlikely that in the sterile environment viable organisms interact with the mucosa of blind loops, non-viable components of the luminal contents might trigger the observed phenomena. Bulk could be one of these harmful factors. But adding bulk even in high concentrations to the fodder does not lead to such mucosal alterations. ${ }^{21}$ On the other hand, it is not known what effects these substances could have when forced into these isoperistaltic loops where they are largely accumulated.

Apart from mechanical factors, immunological events could be responsible for the observed morphological phenomena. Under physiological conditions, the intestinal contents slowly pass down the small bowel from the duodenum to the colon and the time for interactions between chyme and small intestine is limited. By contrast, the contents of the blind loops are retained under pressure in the isoperistaltic self-filling segments thus increasing the time of contact between ingesta and mucosa. It is possible that this situation leads to a more intensive contact of antigenic material to the mucosa. On the other hand, the antigen exclusion might be reduced. In germ free animals, this could be due to lesser developed gut associated lymphatic tissue. In conventional and germ free animals, an impaired immunological response could also result from the malabsorption syndrome with the consecutive caloric deficit. ${ }^{22}$ The hypothesis that immunological events may occur during bacterial overgrowth is supported by the demonstration of necrosis of individual enterocytes in villus and crypt epithelium of self-filling blind loops. An increased proliferation, as observed in the model used, can also be found in immunological processes taking place in the small bowel mucosa. ${ }^{23}$

Both mechanisms discussed seem to be attractive explanations for the observed mucosal hyperplasia in self-filling blind loops of germ free rats. It must be admitted, however, that other hitherto unknown factors may also be responsible for the described phenomenon.

*The work was supported by the Deutsche Forschungsgemeinschaft (Me 703/1-2)

\section{References}

1 Tabaqchali S. The pathophysiological role of small intestinal bacterial flora. Scand J Gastroenterol 1970; suppl: 6: 139-63.

2 Isaacs PET, Kim YS. The contaminated small bowel syndrome. Am J Med 1979; 67: 1049-57.

3 Menge $\mathrm{H}$. Blindsacksyndrom. In: Caspary W, ed. Handbuch der inneren Medizin. Band 3/3B, BerlinHeidelberg-New York: Springer Verlag, 1983: 388413.

4 Giannella RA, Rout WR, Toskes PP. Jejunal brush border injury and impaired sugar and amino acid uptake in the blind loop syndrome. Gastroenterology 1974; 67: 965-74.

5 Menge H, Köhn R, Dietermann KH, Lorenz-Meyer H, Riecken EO, Robinson JWL. Structural and functional alterations in the mucosa of self-filling intestinal blind loops in rats. Clin Sci 1979; 56: 121-31.

6 Bloch R, Menge H, Lorenz-Meyer H, Stöckert HG, Riecken EO. Functional, biochemical and morphological alterations in the intestines of rats with an experimental blind-loop syndrome. Res Exp Med 1975; 166: $67-78$.

7 Menge H, Simes G, Germer Ch-Th, Wagner J, Hahn $H$, Riecken EO. Die qualitative und quantitative Erfassung der Bakterienflora beim experimentellen Blindsacksyndrom der Ratte. $Z$ Gastroenterol 1985; 23: 42531.

8 Clarke RM. Mucosal architecture and epithelial cell production rate in the small intestine of the albino rat. $J$ Anat 1970; 107: 519-29.

9 Hill MJ, Drasar BS. Degradation of bile salts by human intestinal bacteria. Gut 1968; 9: 22-7.

10 Tabaqchali S, Booth CC. Jejunal bacteriology and bilesalt metabolism in patients with intestinal malabsorption. Lancet 1966; 2: 12-15.

11 Tabaqchali S, Hatzioannou J, Booth CC. Bile-salt deconjugation and steatorrhoea in patients with the stagnant-loop syndrome. Lancet 1968; 2: 12-16.

12 Midtvedth T. Microbial bile acid transformation. Am J Clin Nutr 1974; 27: 1341-7.

13 Riepe SP, Goldstein J, Alpers DH. Effect of secreted Bacteroides proteases on human intestinal brush border hydrolases. J Clin Invest 1980; 66: 314-22.

14 Joneas A, Flanagan PR, Forstner GG. Pathogenesis of mucosal injury in the blind loop syndrome: brush border enzyme activity and glycoprotein degradation. J Clin Invest 1977; 60: 1321-30.

15 Gracey M, Houghton M, Thomas J. Deoxycholate depresses small-intestinal enzyme activity. Gut 1975; 16: 53-6.

16 Gutschmidt S, Sandforth F, Menge H, Riecken EO. The adaptive response of a- and $\beta$-glucosidase kinetics along the villi of rat self-filling jejunal blind loops. Gut 1982; 23: $376-81$.

17 Burke V, Gracey M, Thomas J, Malajczuk A. Inhibition of intestinal amino acid absorption by unconjugated bile salts in vivo. Aust NZ J Med 1975; 5: 430-2.

18 Burke V, Gracey M, Thomas J, Malajczuk A. Inhibition of intestinal uptake of amino acids by unconjugated bile salts. AJEBAK 1976; 54: 391-402.

19 Menge $\mathrm{H}$, Murer $\mathrm{H}$. Untersuchungen zum $\mathrm{Na}^{+}$-abhängi- 
gen D-Glukose-Transport von Bürstensaumvesikeln unterschiedlicher Adaptationsformen der Dünndarmschleimhaut. Schweiz Med Wochenschr 1985; 115: 1032-3.

20 Gracey M, Papadimitriou J, Burke V, Thomas J, Bower G. Effects on small-intestinal function and structure induced by feeding a deconjugated bile salt. Gut 1973; 14: 519-28.

21 Ecknauer R, Sircar B, Johnson LR. Effect of dietary bulk on small intestinal morphology and cell renewal in the rat. Gastroenterology $1981 ; 81$ : 781-6.

22 Carlomagno MA, Alito AE, Almiron DJ, Gimeno A. T and $B$ lymphocyte function in response to a protein-free diet. Infect Immun 1982; 38: 195-200.

23 Mowat AM, Ferguson A. Intraepithelial lymphocyte count and crypt hyperplasia measure the mucosal component of the graft-versus-host reaction in mouse small intestine. Gastroenterology 1982; 83: 417-23. 